\title{
Breastfeeding in H IV-positive women: do the benefits outweigh the risks?
}

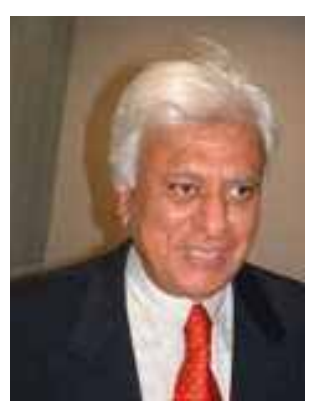

Hoosen Coovadia

U niversity of Kwazulu-N atal, D orisD uke M edical Research Institute, $\mathrm{N}$ elson $\mathrm{M}$ andela School of M edicine, 719 U mbilo Road, Congella 4013, South Africa E-mail: coovadiah@ ukzn.ac.za
'The future chronicles of HIV/AIDS may also linger on the effects on infants and children of choic es made by HIV-positive women on infant feeding and dwell a moment on the lasting imprint of these choic es on human health.'

This editorial compares the advantages and disadvantages of formula milks and breastfeeding for HIV-positive women within the context of improving child survival rather than just reducing vertical transmission of H IV. It is suggested that the risk of HIV transmission through breastfeeding is outweighed by improved child survival. Formula poses zero risk for H IV transmission but renders infants vulnerable to other common infections, resulting in malnutrition and sickness, and compromises a child's basic human right to life. The balance of probabilities suggests that breastfeeding is the better option for HIV-positive women in developing countries, with a corollary that the existing data on interventions reducing breastfeeding transmission be expanded by further research. It is questionable whether formula feeding can be freed of contamination within impoverished environments by offering piecemeal measures targeted at improving domestic hygiene. Poverty reduction, which is self-evidently the best solution, is a long-term project. M easures should be introduced during early childhood to increase the opportunities for the full realization of the potential of all African children, including those born to H IV-positive mothers.

\section{Breastfeeding versus formula feeding for HIV-positive mothers}

A clearer and more objective account of the H IV/AIDS pandemic and a deeper analysis of its impact on the world and its peoples, will only be written in the decades if not centuries ahead. Six centuries after the 'Black D eath', historians and scientists are still examining archival material and reporting the devastation caused by that terrible plague and uncovering its long-term consequences $[1,2]$. The future chronicles of H IV/AIDS may also linger on the effects on infants and children of choices made by HIV-positive women on infant feeding and dwell a moment on the lasting imprint of these choices on human health. Today, the strong preferences by health professionals for either breastfeeding or replacement feeding (mostly formula feeding) for H IV-positive mothers have often drowned out cool and rational discourse [3]. The key arguments are whether the multiple benefits of breastfeeding outweigh its disadvantage in increasing the risk of transmission of the virus, against the zero risk of transmission through formula feeding countered by exposure to the increased risks of mortality and morbidity from common childhood diseases. A prime difficulty is the failure of proponents to handle these two opposing perspectives on the subject simultaneously and arrive at a reasonable conclusion based on the balance of probabilities. The debate is frozen on reducing HIV transmission from mothers to their infants. There are revealing examples from some developing countries, recipients of the recent surge in global AID S funds, that demonstrate the utility of carefully balancing priorities so as to ensure realization of the first and most basic human right - the right to life [101]. In $\mathrm{H}$ aiti, for example, a considerable reduction of motherto-child transmission through the use of prophylactic antiretrovirals (ARVs) and formula implemented through a very comprehensive program was not accompanied by a decrease in extremely high levels of child mortality [4], and increased access of ARVs to adults was associated with a worsening "of every other health indicator" [101]. The position argued in this editorial is that survival of all infants and children, those born to HIV-positive women whether they are HIV infected or not, and those born to H IV-uninfected women, should be the primary goal. M inimizing, and even eliminating, H IV transmission is a parallel and central objective within the context of improved survival. We are on the brink of achieving both aims, reduced transmission and increased survival, and we are likely to succeed as long as the search for ways of making breastfeeding safe from transmitting H IV continues [102]. 
Why breastfeeding is best for most HIV-positive women

There is new evidence that supports continued breastfeeding for the overwhelming majority of H IV-infected women [102]. Three-quarters of all women living with HIV, some 13.2 million of the global total of 38.6 million people infected worldwide, live in sub-Saharan Africa [103] and most are poor. It follows that our public health policies on HIV and infant feeding should be primarily, though not exclusively, aimed at this disadvantaged population.

\footnotetext{
'It is clear that transmission continues throughout breastfeed ing...this route can a ccount for a pproxima tely $44 \%$ of overa ll transmission'
}

There are numerous recent reviews that have confirmed that HIV transmission from mothers to infants has been successfully and dramatically reduced in industrialized countries $[3,5,6,7]$. The rates have decreased from approximately $25-2 \%$ and in some instances fallen to zero [8]. There is also little doubt that avoidance of breastfeeding and prophylactic ARVs, inter alia, have been important in attaining this success. H owever, we have learned from numerous examples in the history of the twentieth century that technologies that were highly effective in rich countries often fail miserably when transplanted into developing countries $[9,10,101]$. The reason for caution in the case of infant feeding choices made by HIV-infected women is that avoidance of breastmilk removes a wall of protection against pathogenic microbes inhabiting the local environments of infants born to HIV-positive women. These organisms gain entry to infants through contaminating water and foods fed to babies, and proliferate unchecked in the immature bowels of infants. These exposures lead to a failure to grow, overt malnutrition, diarrhea, pneumonia, hospitaliza tion for severe illnesses and finally death [11]. These consequences of formula feeding have been known for more than a century and carefully documented for H IV-uninfected women during the latter part of the 20th century.

$\mathrm{O} n$ the other hand, the risks of prolonged breastfeeding can be quite high. The estimates of these risks made by different studies from a number of African countries throughout the continent have been reported in recent reviews. It is clear that transmission continues throughout breastfeeding; therefore, in the worst-case scenario, when breastfeeding lasts between
18 and 24 months, this route can account for approximately $44 \%$ of overall transmission (i.e., transmission during the antenatal, intrapartum and postnatal periods) [12]. There remains some uncertainty whether the first few months of breastfeeding pose a higher risk of transmission than later periods. This is partly due to the inability to distinguish breastfeeding transmission in the first month of life from that due to antenatal and intrapartum transmission. In a meta-analysis of results from a number of trials comprising more than 3000 infants with negative H IV tests at 4 weeks of age, the overall risk of breastfeeding transmission was 8.9 transmissions per 100 child-years of breastfeeding; this is easier to remember as $0.74 \%$ transmission for every month of breastfeeding [13].

The key risk factors for breastfeeding transmission of HIV, derived from a number of reviews [14-16,104,105], are given in Figure 1 . The harmful effects of many of these factors can be minimised; in fact, a few studies have already shown that levels of breastfeeding transmission can be lowered substantially. A list of these studies [17-22]; [Sinkala M. Pers. Comm.], together with a few details, is given in Table 1. It is worth reiterating that the optimal duration of exclusive breastfeeding is 6 months, beyond this the infant and child require additional foods. Breastfeeding often continues beyond 6 months up to 24 months in many developing countries, as there are advantages to the mothers and their infants. The range of interventions to reduce breastfeeding transmission of H IV while hopefully retaining its beneficial properties for child survival include immunoprophylaxis using vaccines and HIV antibodies, chemoprophylaxis through ARVs for mothers or babies or both during breastfeeding, neutralization or elimination of H IV particles by treatment of breastmilk with ARVs or safe detergents, and scaling-up exclusive breastfeeding and provision of highly active antiretroviral therapy (H AART) for pregnant and lactating women with severe and moderate immunosuppression who are at especially high risk of transmitting the virus [102].

\section{Breastfeeding by HIV-infected women beyond 6 months}

The disastrous consequences of avoidance or too early cessation of breastfeeding, which have been pointed out previously, have been recognized during the past 2 years by researchers working among African infants born to HIV-infected women [7,11,102]. Impoverished HIV-infected 


\section{Figure 1. Risk factors for breastfeeding transmission of HIV-1.}

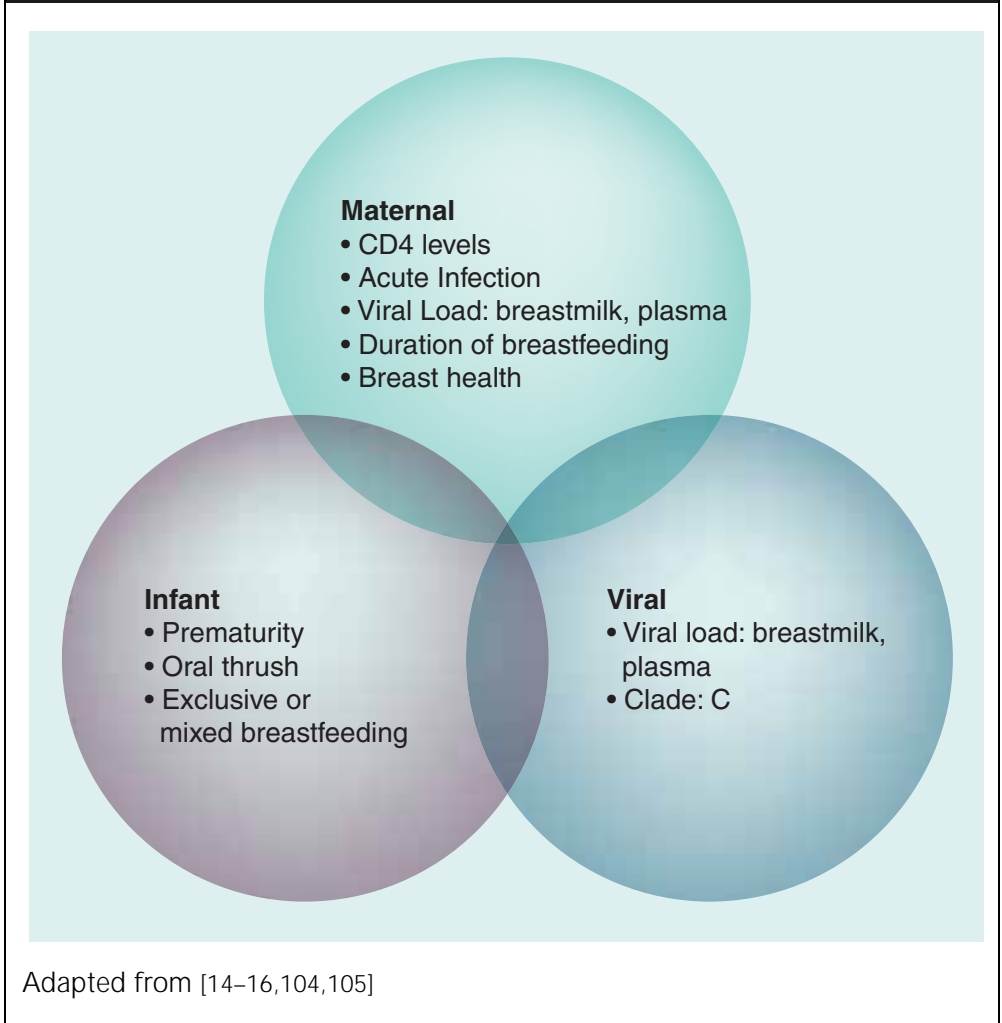

women often have little or no food security and their local environment may be insufficient to provide nutritionally adequate complementary foods for their infants after 6 months, when exclusive breastfeeding is insufficient of itself [22]. These women are compelled by circumstances to continue breastfeeding so as not to waste a useful natural resource. The risk of HIV transmission beyond 6 months remains a hazard they are unable to avoid. At present, many such women are more or less left to their own devices. Work on preserving the nutritional and anti-infective benefits of breastmilk whilst reducing the risk of HIV transmission is being undertaken currently. The measures used to achieve these twin aims include the use of some of the interventions described previously for the reduction of breastfeeding transmission of H IV.

Can we make formula feeding safe for HIV-positive women in poor populations?

The simple and obvious answer is 'yes', if Frantz Fanon's 'wretched of the earth' [23] had similar levels of material resources and development to their counterparts in the richer nations of the world. The more complicated response is that this is unlikely to make a meaningful public health impact given the scale of the service delivery shortages in countries reeling from the impact of HIV /AID S and the financial and trade imbalances in the globalized economy. The social needs of the poor are staggering. Reports of the global position show that there are more than 1 billion people without access to clean water and 2.6 billion people without adequate sanitation $[24,25]$. This is the world's environment that results in 1.8 million deaths in children from diarrhea and other preventable diseases. In regions of sub-Saharan Africa worst affected by H IV/AIDS, the lack of assured services of clean water cause fivetimes more deaths than HIV/AIDS in children. There is a 'water crisis' and with increasing threats to the sustainability of clean water supplies from global warming, the position is unlikely to improve in the near future. The absolute physical deficits in water supply are an external manifestation of disordered societies crippled by "poverty, inequality and unequal power relationships, as well as flawed water management policies" [24]. While there is agreement that global funds, especially for the control of HIV/AIDS in poor countries, have produced significant benefits, there are doubts concerning the fulfillment of promises made regularly by the richest nations and concerns regarding the infrastructural capacity and other characteristics of resource-limited countries to absorb and effectively use large monetary grants [101]. In a word, poverty, which is the fundamental cause of the limitations on use of formula among H IV-positive women, is unlikely to be reversed or substantially ameliorated in the near future to make formula safe. H IV-positive women and the communities in which they live require solutions now.

Small-scale efforts aimed at providing free formula and household materials (stoves, kerosene, bottles and other general assistance) to poor H IVpositive women in order to render formula free of contamination will probably fail or be unsustainable without huge external investment [26]. The latter would exacerbate the dependency on rich countries, which is the bane of the modern world. These interventions may work in some select communities in middle-income countries. W hat is needed are solid data that such an intervention can be effective and this evidence is still unavailable. At present, we have some graphic evidence from Botswana (a country with endemic H IV but an enviable growth rate and advanced infrastructure compared with other developing countries) that even with electricity and clean 


\section{Table 1. Current studies on reducing breastfeeding transmission of HIV-1.}

\begin{tabular}{|c|c|c|c|}
\hline Intervention & Study/site & Main finding & Ref. \\
\hline \multirow[t]{6}{*}{ EBF } & Durban, South Africa & $\begin{array}{l}\text { Overall transmission in EBF at } 6 \text { months identical to formula rate: } 19.4 \% \\
\text { MBF: } 26.1 \%\end{array}$ & [17] \\
\hline & Zvitambo, Zmbabwe & $\begin{array}{l}\text { Transmission between } 4 \text { weeks and } 6 \text { months in: } \\
\text { EBF: } 1.31 \% \\
\text { MBF: } 4.40 \% \\
\text { And at } 12 \text { months: } \\
\text { EBF: } 3.42 \% \\
\text { MBF: } 8.41 \%\end{array}$ & [18] \\
\hline & $\begin{array}{l}\text { Africa Center, South } \\
\text { Africa }\end{array}$ & $\begin{array}{l}\text { Transmission between } 4 \text { weeks and } 6 \text { months in: } \\
\text { EBF: } 4.04 \% \\
\text { MBF with solids: } 10 \text {-times higher than EBF } \\
\text { M BF with formula: approximately 2-times higher than EBF }\end{array}$ & [19] \\
\hline & Abidjan, Côte d' Ivoire & $\begin{array}{l}\text { Postnatal infections per child year } \\
\text { EBF: } 5.9 \% \\
\text { MBF: } 31.6 \%\end{array}$ & [20] \\
\hline & Lusaka, Zambia & $\begin{array}{l}\text { Cumulative probability of HIV infection by } 4 \text { months } \\
\text { EBF: } 4.0 \% \\
\text { MBF: } 10.1 \%\end{array}$ & $\begin{array}{l}\text { [Sinkala M. } \\
\text { Pers. Comm. }\end{array}$ \\
\hline & Kampala, Uganda & $\begin{array}{l}\text { Overall transmission by } 6 \text { weeks } \\
\text { EBF: } 11.2 \% \\
\text { MBF: } 17.1 \% \\
\text { At } 12 \text { months: } \\
\text { EBF: } 16 \% \\
\text { MBF: } 20.4 \%\end{array}$ & [21] \\
\hline $\begin{array}{l}\text { Maternal } \\
\text { HAART }\end{array}$ & $\begin{array}{l}\text { Botswana, Mozambique, } \\
\text { Uganda, }\end{array}$ & $\begin{array}{l}\text { There are '.... indications that maternal HAART for treatment-eligible } \\
\text { women may reduce postnatal HIV transmission...' }\end{array}$ & {$[102]$} \\
\hline
\end{tabular}

EBF: Exclusive breastfeeding; HAART: Highly active antiretroviral therapy; MBF: Mixed breast feeding.

water available to households, the use of freely available formula milks was significantly associated with a lack of protection against a massive outbreak of diarrhea and hundreds of deaths in children [27]. The failure to maintaining a clean water supply, resulting in contamination of the water source for the population, was the root cause of this catastrophe. These types of events occur even in the industrialized world. Abandoning a centuries-old practice that comes at no cost, confers substantial protection against infections and promotes optimal growth and development of children in poor countries for the uncertainties of formula feeding demands great circumspection and the most compelling evidence. The better option is to make breastfeeding safe for babies born to H IV-positive women; and we are nearing this goal.

'The betteroption is to make breastfeeding safe forbabiesborn to HIV positive women; and we are nearing this goal.'
Lastly, we need to go beyond survival and measure the worth of children born to H IV-positive women by more subtle indicators and not only by extreme outcomes, such as severe illness and death. It is time to add to our rightful preoccupation with reducing morbidity and mortality a deeper concern for exploring interventions that will maximize their cognitive potential and life chances as adults. There are a number of affordable interventions that can produce lasting effects if introduced early in life [28]. B reastfeeding, for one, is recognized to produce long-term benefits persisting into adulthood [29,30]; what would be the long-term impact of formula feeding?

\section{Future perspective}

In industrialized countries, HIV-infected newborns will become even fewer than at present and will no longer present a public health problem. The concerns for rich populations will be management of the longer-term physical, emotional and psychological outcomes of HIV-infected children, adolescents and adults who have been infected during infancy. 


\section{Breastfeeding in H IV-positive women - ED IT O RIAL}

The solutions to minimizing breastfeeding transmission of HIV will be established in principle. In Africa and Asia these will be introduced and gradually scaled-up. These countries will need to vastly improve the quantity and quality of their health systems so as to increase coverage of other interventions known to prevent or treat HIV infection in children, while at the same time providing health services for all children. Select groups or communities in middle-income, and maybe even in some poor countries, will continue to use formula milks for HIV-infected and HIVuninfected women.

Financial \& competing interests disclosure The authors have no relevant affiliations or financial involve ment with any organization or entity with a financial interest in or financial conflict with the subject matter or materials discussed in the manuscript. This indudes employment, consultancies, honoraria, stock ownership or options, expert testimony, grants or patents received or pending or royalties.

$\mathrm{N}$ o writing assistance was utilized in the production of this manuscript.

\section{Bibliography}

Papers of special note have been highlighted as either of interest $(\bullet)$ or of considerableinterest $(\bullet \bullet$ to readers.

1. Christakos G, O lea RA, Yu H L: Recent results on the spatiotemporal modeling and comparative analysis of Black D eath and bubonic plague epidemics. J. Public $\mathrm{H}$ ealth (2007) (In Press).

2. M cN eill WH : Plagues and Peoples. Anchor Books, N ew York, U SA (1977).

3. Coovadia H, Bland R: Preserving breastfeeding during the HIV pandemic. Trop. M ed. Int. H ealth (2007) (Epub ahead of print).

- Recent data on breastfeeding transmission.

4. Noel F, Wright PF, Bois P et al.: Contribution of bacterial sepsisto morbidity in infants born to H IV-infected H aitian mothers. J. Acquir. Immune D efic. Syndr. 43, 313-319 (2006).

5. Bulterys $\mathrm{M}$ : Preventing vertical transmission in the year 2000: Progress and Prospects Review. Placenta 22, S5-S12 (2001).

6. M ofenson L: Advances in the prevention of vertical transmission of human immunodeficiency virus. Semin. Pediatr. Infect. D is. 14, 295-308 (2003).

7. Wilfert $\mathrm{CM}$, Fowler M G: Balancing maternal and infant benefits and the consequences of breastfeeding in the developing world during the era of H IV infection. J. Infect. D is. 195, 165-167 (2007).

- Concise account, including data from unpublished studies, of disadvantages of too early cessation of breastfeeding in babies born to H IV-positive mothers.

8. N aver $L$, Lindgren $S$, Belfrage $E$ et al.: Children born to HIV-1 infected women in Sweden in 1982-2003: trends in epidemiology and vertical transmission J. Acquir. Immune D efic. Syndr.. 42(4), 484-489 (2006).

9. Freebairn DK: Did the green revolution concentrate incomes? A quantitative study of research reports. World D ev. 23, 265-279 (1995).

10. Lipton M , Longhurst R: N ew Seeds And Poor People. Johns H opkins U niversity Press, Baltimore, USA (1989).

11. Cooovadia H, Coutsoudis A: Survival and feeding of infants born to H IV-infected women. Although this is new wine in old bottles, the recent data refine $U \mathrm{~N}$ Guidelines and highlight research priorities. AIDS (2007) (In Press).

- Editorial on disadvantages of avoidance or too early cessation of breastfeeding in babies born to H IV-positive mothers.

12. N duati $R$, John $G, M$ bori-N gacha $D$ et al.: Effect of breastfeeding and formula feeding on transmission of HIV-1: a randomized clinical trial. JAM A 283, 1167-1174 (2000).

- Only randomized, controlled trial of breastfeeding versus formula feeding in babies born to H IV-positive mothers.

13. The Breastfeeding and H IV International Transmission Study Group: M ortality among H IV infected women according to childrens' feeding modality. J. Acquir. Immune D efic. Syndr. 39, 430-438 (2005).

- Meta-analysis of breastfeeding studies.

14. John-Stewart GC, M bori-N gacha D, Ekpini ER: Breastfeeding and transmission of HIV-1. J. Acquir. Immune D efic. Syndr. 35(2), 196-202 (2004).

15. Kourtis A, Butera S, I begbu C, Belec L, Duerr A: Breastmilk and HIV-1: vector of transmission or vehicle of protection? L ancet 3, 786-793 (2003).

- Immunopathogenesis of breastfeeding transmission of H IV-1.

16. WHO, UNICEF, UNAIDS, UNFPA: HIV Transmission Through Breastfeeding: A Review Of Available Evidence. World $\mathrm{H}$ ealth O rganisation, G eneva, Switzerland (2004).

- Comprehensive record of HIV-1 transmission from mothers to infants.

17. Coutsoudis A, Pillay K, Spooner E, Kuhn L, Coovadia H M , for the South African Vitamin K Study Group: Influence of infant-feeding patterns on early mother-tochild transmission of HIV-1 in D urban, South Africa: a prospective cohort study. Lancet 354, 471-476 (1999).

18. Iliff PJ, Piwoz EG, Tavengwa N V et al.: Early exclusive breastfeeding reduces the risk of postnatal HIV-1 transmission and increases H IV-free survival. AIDS 19(7), 699-708 (2005)

- Transmission of HIV-1 due to different modalities of breastfeeding.

19. Coovadia H M, Rollins N C, Bland RM et al.: M other-to-child transmission of HIV-1 infection during exclusive breastfeeding in the first 6 months of life: an intervention cohort study. Lancet 369, 1107-1116 (2007).

- Transmission of HIV-1 during exclusive and mixed breastfeeding.

20. Leroy $\mathrm{V}$, Becquet $R$, Rouet $F$ et al.: Postnatal transmission risk according to feeding modalities in children born to H IV-infected mothers in a PM TCT project in Abidjan, Côte d'Ivoire. Ditrame Plus AN RS 1201/1202. O ral Poster ( $N$ N M oPpB2007) presented at: The XV International AIDS Conference, Bangkok, Thailand, Jul 11-16 2004.

21. M agoni $M$, Bassani $L, O$ kong $P$ et al.: $M$ ode of infant feeding and H IV infection in children in a program for prevention of mother-to-child in U ganda. AIDS 19(4), 433-437 (2005).

22. Johnson $W$, Alons $C$, Fidalgo $L$ et al.: The challenge of providing adequate infant nutrition following early breastfeeding cessation by H IV-positive, food-insecure M ozambican mothers. Presented at: XVI International AIDS Conference, Toronto. Canada, 13-18 August 2006.

23. Fanon F: The Wretched of the Earth. G rove Press, N ew York, USA (2005).

24. H uman D evelopment Report 2006: Beyond Scarcity: Power, Poverty And The G lobal Water Crisis. United $N$ ations $D$ evelopment Programme, N ew York, U SA (2006). 
- Provides the scale of poverty in relation to public health; of importance to recommendations for formula feeding.

25. UNICEF: The State of the World's C hildren 2007. Women and Children. The double dividend of gender equality. UNICEF, UN ICEF H ouse, N ew York, USA (2006).

26. Farmer PE, N izeye B, Stulac S, Keshavjee S: Structural violence and clinical medicine. PLOS M ed. 3, 1686-1691 (2006).

27. Creek T, Arvelo W, Kim A et al.: Role of infant feeding and hiv in a severe outbreak of diarrhea and malnutrition among young children, Botswana, 2006. 14th Conference of Retroviruses and 0 pportunistic Infections. Los Angeles, California, USA (1997) (Abstract 770)

28. Grantham-M CG regor $S, C$ heung $Y B$, Cueto $S$ et al.: $D$ evelopmental potential in the first 5 years for children in developing countries. Lancet 369, 60-70 (2007).
29. Jones G, Steketee RW, Black RE et al.: Child Survival Study Group. H ow many child deaths can we prevent this year? L ancet 362 , 65-71 (2003).

30. Singhal A, Lucas A: Early origins of cardiovascular disease: is there a unifying hypothesis? Lancet 363, 1642-1645 (2004)

\section{Websites}

101. Garrett L: The Challenge of $\mathrm{G}$ lobal $\mathrm{H}$ ealth. Foreign Affairs. January/February 2007. www.foreignaffairs.org

102. WHO HIV and Infant Feeding Technical Consultation held on behalf of the interagency task team on prevention of H IV infections in pregnant women, mothers and their infants. G eneva, 0 ctober 2006. www.who.int/child-adolescenthealth/N ew_Publications/N UTRITIO N/co nsesus_statement.Pdf
103. N ew guidelines from $\mathrm{WH} O \mathrm{O}$ based on recent evidence on modalities of breastfeeding and H IV-1 transmission, and data on avoidance or too early discontinuation of breastfeeding in babies born to HIV positive mothers report on the global AIDS epidemic 2006. www.unaids.org/en/HIV_data/2006G lobal Report/default.asp-17k-

104. Bulterys M, N olan M, Jamieson D, D ominguez $\mathrm{K}$, Fowler $\mathrm{M}$ : Advances in the prevention of mother-to-child H IV-1 transmission: current issues, future challenges. AID Science, 2 (2002) N 0.4. http://aidsscience.org/articles/aidsscience 01 7.asp.

105. Coovadia H, Coutsoudis A: Problems and advances in reducing transmission of H IV-1 through breast-feeding in developing countries. AID Science 1(2001) N 0. 4. http://aidsscience.org/articles/aidsscience00 4.asp. 